\title{
Activated human monocytes exhibit receptor-mediated adhesion to a non-enzymatically glycosylated protein substrate
}

\author{
M.Z. Gilcrease and R. L. Hoover \\ Department of Pathology, Vanderbilt University, Nashville, Tennessee, USA
}

\begin{abstract}
Summary. Non-enzymatic glycosylation of proteins is thought to play an important role in the development of diabetic vascular disease. Advanced glycosylation end products have been shown to accumulate on basement membranes and collagen in diabetes, and receptors for such adducts have recently been found on murine macrophages. We have observed that human monocytes activated by endotoxin express receptors for advanced glycosylation end products of similar affinity and number as has been previously reported for murine macrophages. In addition, there is an increased adherence of activated human monocytes to a non-
\end{abstract}

enzymatically glycosylated albumin substrate, and such adhesion can be competitively inhibited up to $50 \%$ by soluble, non-enzymatically glycosylated albumin. We suggest that increased adherence of activated monocytes to non-enzymatically glycosylated proteins in the vessel wall may result in monocyte stimulation and/or local monocyte accumulation and thereby contribute to vascular disease in diabetes.

Key words: Monocyte, glucose, endotoxin, adhesion, nonenzymatic glycosylation, advanced glycosylation end product receptor.
Although the role of hyperglycaemia in the development of diabetic vascular disease is unclear, there is growing evidence which suggests that the non-enzymatic glycosylation of proteins following exposure to high concentrations of glucose may be important in the pathophysiology of the disease [1-5]. Glucose reacts rapidly with amino groups of proteins to form reversible Schiff bases, which rearrange to form ketoamines [2]. These adducts accumulate during periods of hyperglycaemia until equilibrium is reached, but the process is reversed after glucose levels are normalized by treatment. A slow rearrangement of the ketoamines takes place, however, which is not reversible. Advanced glycosylation end products (AGE) are formed by this rearrangement, and they continue to accumulate throughout the lifetime of the protein $[2,4-9]$.

A receptor for AGE has recently been identified on murine macrophages $[10,11]$. Purification from membranes of the macrophage cell line RAW 264.7 has revealed that the receptor has two peptide subunits. One is an 83,000-dalton subunit which is involved in ligand binding. The other, a 36,000-dalton subunit, is of unknown function [12]. Although there have now been several reports describing the AGE-receptor on murine macro- phages $[10,11,13]$, no data for AGE-receptors on human cells have yet been published. This study uses isolated human monocytes to determine whether they express AGE-receptors similar to those found on murine macrophages. As it is thought that such receptors mediate binding to interstitial AGE-proteins, this study also evaluates the specific binding of human monocytes to an AGE-protein substrate.

\section{Materials and methods}

\section{Monocyte isolation}

Monocytes were separated from whole human blood using Sepracell-MN (Sepratech Corporation, Oklahoma City, Okla., USA) [14]. Blood was collected into EDTA-vacutainer tubes, and $25 \mathrm{ml}$ blood was mixed with $25 \mathrm{ml}$ Sepracell-MN and centrifuged at $1500 \times \mathrm{g}$ for $20 \mathrm{~min}$. The mononuclear layer was removed, washed, and resuspended in $4 \mathrm{ml}$ Dulbecco's Phosphate-buffered Saline (PBS, Gibco Laboratories, Grand Island, NY, USA) with $0.1 \%$ bovine serum albumin (BSA, Sigma Chemical Company, St. Louis, Mo., USA), and $6 \mathrm{ml}$ Sepracell-MN was added. Following another centrifugation at $1500 \times g$ for $20 \mathrm{~min}$, the top layer was collected, mixed with an equal volume of $\mathrm{PBS}$ with $0.1 \% \mathrm{BSA}$, and centrifuged for $10 \mathrm{~min}$ at 


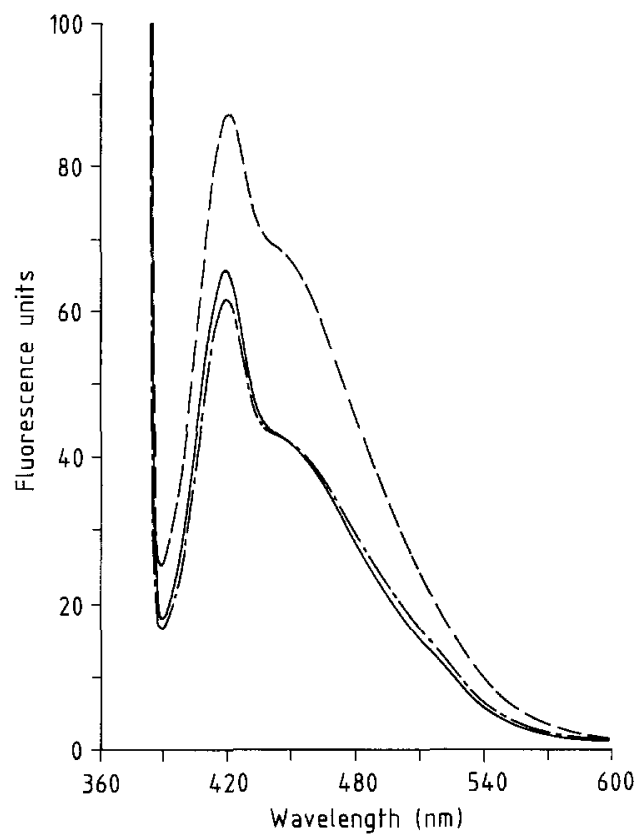

Fig. 1. Emission spectra of fresh bovine serum albumin (BSA) $(-\longrightarrow)$, control BSA ( - - $)$, and advanced glycosylation end product-BSA (AGE-BSA) ( $\ldots$ - ) following excitation at $370 \mathrm{~nm}$

$300 \times g$ to remove platelets. After a final wash, alpha-naphthyl acetate esterase staining and haematoxylin counterstaining revealed a monocyte purity of $94 \%$. The monocytes were then incubated with lipopolysaccharide B (E. Coli 0127: B8, Difco Laboratories, Detroit, Mich., USA) at a concentration of $10 \mu \mathrm{g} / \mathrm{ml}$ at $37^{\circ} \mathrm{C}$ for $1 \mathrm{~h}$. The monocytes used in adherence assays were subsequently labelled at $4{ }^{\circ} \mathrm{C}$ for $1 \mathrm{~h}$ with ${ }^{51} \mathrm{Cr}(100 \mu \mathrm{Ci} / \mathrm{ml}$ of cell suspension, New England Nuclear, Boston, Mass., USA), rinsed, and resuspended at a concentration of $2 \times 10^{5}$ cells $/ \mathrm{ml}$.

\section{Preparation of $A G E-B S A$}

BSA was non-enzymatically glycosylated by suspending it at a concentration of $1 \%$ in PBS and incubating at $37^{\circ} \mathrm{C}$ for three weeks in the presence of $200 \mathrm{mmol} / \mathrm{l}$ D-glucose. Such treatment has been shown to be sufficient for the accumulation of large amounts of
M.Z. Gilcrease and R. L. Hoover: Activated human monocyte adhesion

AGE on albumin $[9,10]$. Control BSA was treated similarly. Protein substrates were prepared by soaking round glass coverslips (15 mm diameter) for $4 \mathrm{~h}$ at $37^{\circ} \mathrm{C}$ in the above suspensions. The coverslips were then rinsed thoroughly and allowed to air dry. Suspensions were alternatively dialysed overnight to remove free glucose, and aliquots were used for competition adherence experiments and receptor binding assays.

\section{Fluorescence measurements}

Proteins with advanced glycosylation end products are reported to emit increased fluorescence at $430 \mathrm{~nm}$ upon excitation at $370 \mathrm{~nm}[7$ 9]. The emission spectra of AGE-BSA, control BSA, and fresh BSA were measured by preparing suspensions of each $(2 \mathrm{mg} / \mathrm{ml})$ in PBS. The samples were excited at $370 \mathrm{~nm}$ in a spectrophotofluorimeter, and fluorescence tracings were made from $360 \mathrm{~nm}$ to $600 \mathrm{~nm}$.

\section{Receptor binding assays}

Control BSA and AGE-BSA were radioiodinated with carrier-free ${ }^{125}$ I (New England Nuclear) by the IODO-GEN method of Fraker and Speck [15] and recovered by trichloroacetic acid precipitation. Specific activities for BSA and AGE-BSA were $155 \mathrm{cpm} / \mathrm{ng}$ and $113 \mathrm{cpm} / \mathrm{ng}$, respectively. Human blood monocytes were isolated and activated with endotoxin as described above, seeded onto plastic tissue-culture dishes, and allowed to adhere for $2 \mathrm{~h}$ at $37^{\circ} \mathrm{C}$ to produce a monolayer for receptor binding assays [10]. After washing the monolayer, cold PBS was added to the cells, and they were allowed to equilibrate at $4^{\circ} \mathrm{C}$. Binding was initiated by removing the PBS and adding $200 \mu$ l of the incubation medium containing the radioligand. The assay was carried out at $4{ }^{\circ} \mathrm{C}$ for $1 \mathrm{~h}$. The radioligand-containing medium was then aspirated, the cells were washed 3 times, and $1 \%$ sodium dodecyl sulfate was added to each well and left overnight. Cellular protein concentrations were determined using the $\mathrm{Bi}$ cinchoninic Acid Protein Assay Reagent (Pierce, Rockford, Ill., USA), and cell-associated radioactivity was measured by scintillation counting. Specific binding of AGE-BSA was calculated as binding of AGE-BSA minus binding of control BSA.

\section{Monocyte adherence assays}

Coverslips coated with control BSA or AGE-BSA were balanced on the tops of test tubes, and $200 \mu \mathrm{l}$ of a suspension of ${ }^{51} \mathrm{Cr}$-labelled activated monocytes $\left(1 \times 10^{6}\right.$ cells $\left./ \mathrm{ml}\right)$ containing BSA or AGE-BSA

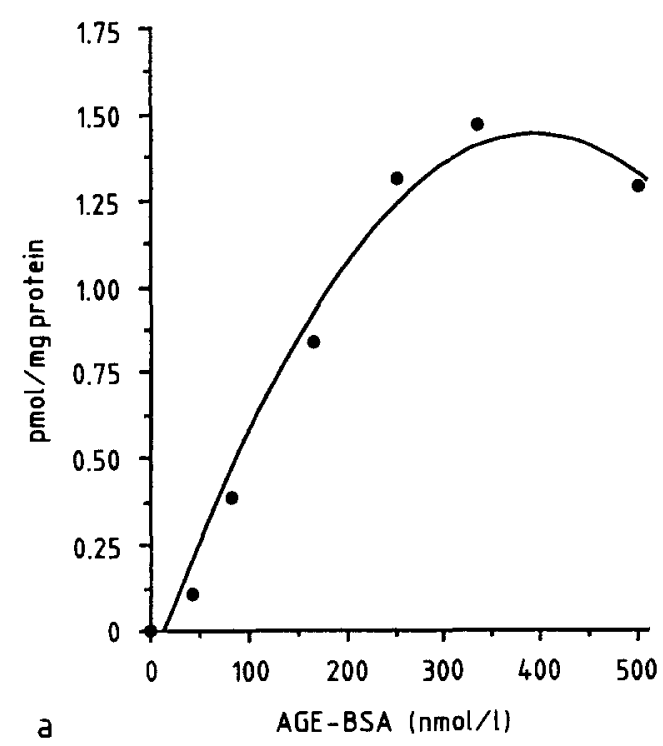

a

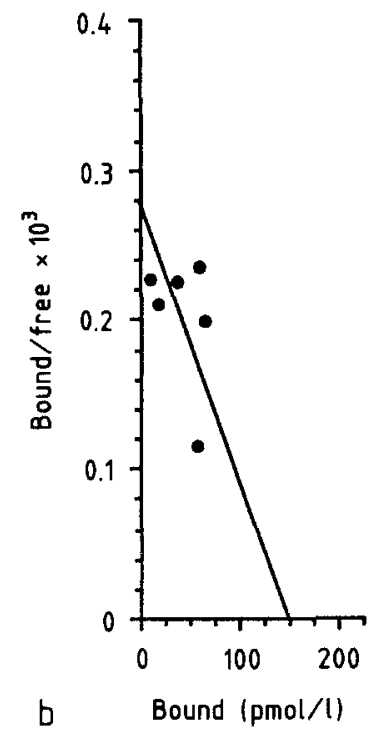

Fig. 2 a, b. Specific binding of ${ }^{125}$ I-labelled advanced glycosylation end product-BSA (AGE-BSA) to human monocytes activated by endotoxin. Data points are means of two experiments performed with duplicate samples. b Scatchard plot of binding data 


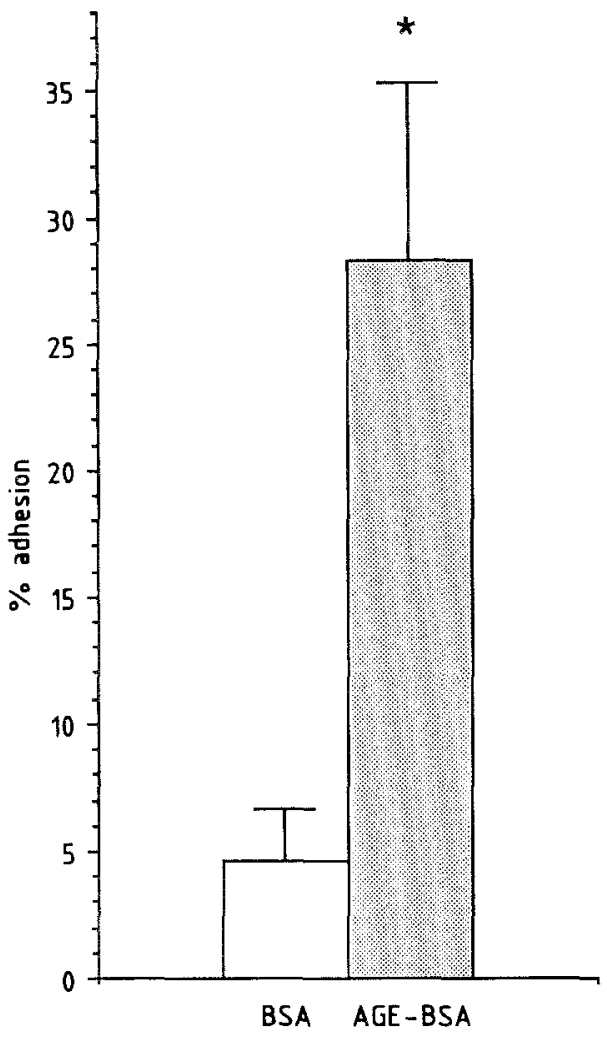

Fig.3. Adhesion of ${ }^{51} \mathrm{Cr}$-labelled activated human monocytes to bovine serum albumin (BSA) ( $\square$ ) vs advanced glycosylation end product-BSA (AGE-BSA) ( ( ) substrates. Error bars represent SEM for three experiments performed in triplicate. * $p<0.05$

$(100 \mu \mathrm{g} / \mathrm{ml})$ was added to each. Following incubation at $37^{\circ} \mathrm{C}$ for 30 min, each coverslip was rinsed thoroughly and left overnight in a scintillation vial with $0.5 \mathrm{ml}$ of $0.5 \mathrm{~mol} / 1 \mathrm{NH}_{4} \mathrm{OH}$. Per cent adherence (calculated as the number of counts remaining on the coverslips following thorough rinsing divided by total counts added at the beginning of the assay) was subsequently quantitated by scintillation counting.

\section{Statistical analysis}

The Student's unpaired $t$-test was used to determine whether values obtained from the monocyte adherence assays were significantly different from control values.

\section{Results}

Proteins with AGE are reported to display characteristic increases in emmission at around $430 \mathrm{~nm}$ following excitation at $370 \mathrm{~nm}$ [7-9]. Figure 1 shows the emission spectra of fresh BSA, AGE-BSA, and control BSA. Incubation without high concentrations of glucose did not affect the emission spectrum of BSA, but BSA incubated with high concentrations of glucose and subsequently dialysed displayed increased fluorescence, consistent with the presence of $\mathrm{AGE}$.

We have been unable to detect specific binding of AGE-BSA to freshly-isolated human blood monocytes. However, we observed saturable specific binding of AGEBSA to human monocytes following activation of the monocytes with endotoxin (Fig. 2a). Scatchard analysis reveals the approximate number of receptors/cell to be $n=3.2 \times 10^{5}$, with a dissociation constant $\mathrm{K}_{\mathrm{d}}$ of $0.5 \times$ $10^{-7} \mathrm{~mol} / 1$ (assuming that one molecule of AGE-BSA binds to one receptor). These values are very similar to those reported for the $\mathrm{AGE}$-receptors found on murine macrophages [10,11]. Competition of AGE-BSA binding with excess cold AGE-BSA produced a $79 \%$ and $86 \%$ inhibition of binding at free labelled AGE-BSA concentrations of $167 \mathrm{nmol} / \mathrm{l}$ and $250 \mathrm{nmol} / 1$, respectively.

As these receptors have been postulated to mediate binding to AGE-protein substrates, we believe a more appropriate receptor assay would entail measuring specific binding of the cells to an AGE-protein substrate. Adherence assays were performed, therefore, using human monocytes and BSA vs AGE-BSA substrates. We could detect no difference in the binding of freshly-isolated human monocytes to BSA vs AGE-BSA substrates (unpublished data). As shown in Figure 3, however, a greater than sixfold increase was observed in the adhesion of endotoxin-activated human monocytes to a substrate of AGE-BSA vs control BSA. That increase was competitively inhibited $50 \%$ when adherence to the AGE-BSA substrate was measured in the presence of soluble AGEBSA (Fig. 4).

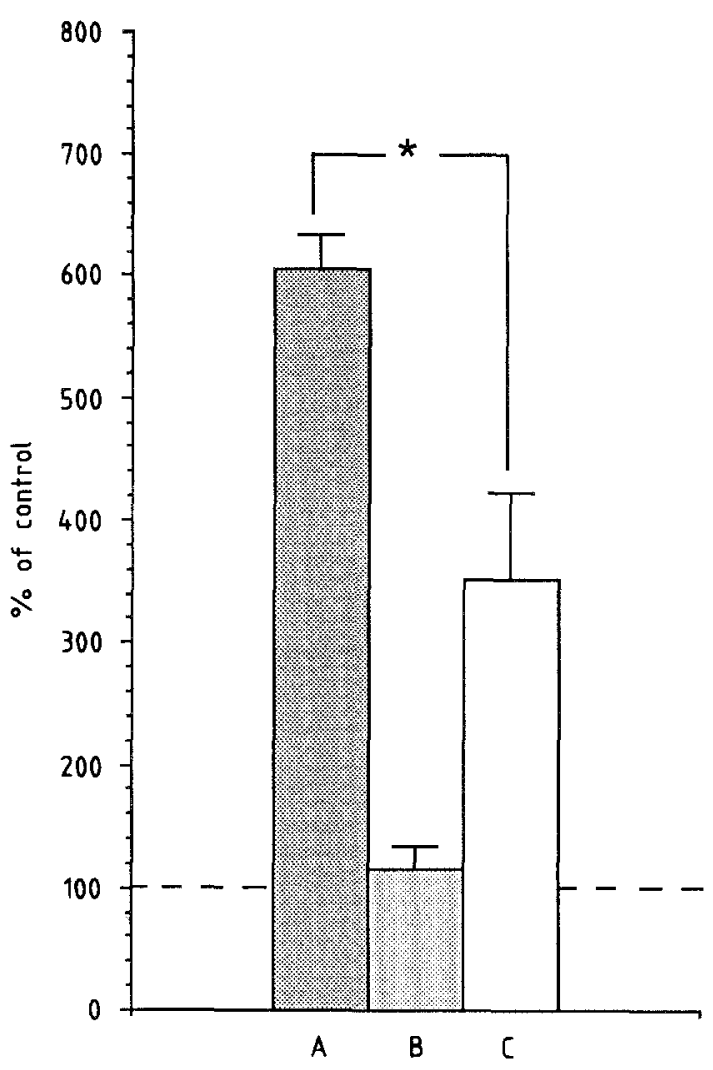

Fig.4. Adhesion of ${ }^{51} \mathrm{Cr}$-labelled activated human monocytes to advanced glycosylation end product-bovine serum albumin (AGEBSA) substrate in the presence of $100 \mu \mathrm{g} / \mathrm{ml}$ BSA (A), to BSA substrate in the presence of $100 \mu \mathrm{g} / \mathrm{ml}$ AGE-BSA (B), and to AGE-BSA substrate in the presence of $100 \mu \mathrm{g} / \mathrm{ml}$ AGE-BSA (C). Control is adhesion to BSA substrate in the presence of $100 \mu \mathrm{g} / \mathrm{ml}$ BSA, and control values on different days ranged from $2.0 \%$ to $5.5 \%$. Error bars represent SEM for three experiments performed in triplicate. $* p<0.05$ 


\section{Discussion}

Receptors for AGE have been found on murine macrophages, and it has been proposed that binding to nonenzymatically glycosylated matrix proteins may play a role in the pathogenesis of diabetic vascular disease [3, $10,11]$. AGE-receptors on murine macrophages have been shown to mediate the binding, uptake, and degradation of a variety of AGE-proteins (proteins which have been exposed to high concentrations of glucose in order to accumulate AGE). This finding suggests that the receptor may enable macrophages to stimulate preferential removal and replacement of older macromolecules which have been cross-linked by long-term exposure to glucose $[4,5]$.

Human monocytes cultured in vitro have been shown to ingest erythrocytes with certain AGE on their surface [16], and cachectin/tumour necrosis factor and interleukin-1 production have been shown to increase following stimulation of human monocytes by glucose-modified proteins [17]. These findings suggest that cultured human monocytes also possess AGE-receptors, but receptor binding data for human monocytes have not previously been published.

We have been unable to detect receptors for AGE on freshly-isolated human monocytes. However, the experiments described above which suggest that human monocytes may express such receptors were performed with cultured human monocytes. The culturing of human monocytes has previously been shown to result in monocyte activation [22]. Therefore, it appeared that activation of blood monocytes may be required for AGE-receptor expression. As endotoxin has been shown to be a potent stimulator of monocyte activation [18-20], we performed receptor binding assays on human monocytes following activation by endotoxin. Activated human monocytes were shown to express AGE-receptors, and the receptor number and affinity constant were shown to be very similar to those reported for murine macrophages $[10,11]$. As the macrophage is essentially an activated blood monocyte [21], the results found for activated human monocytes are consistent with those reported for murine macrophages.

The binding data in Figure 2 was obtained using a monolayer receptor-binding assay similar to that used to study AGE-receptors on murine macrophages $[10,11]$. The binding of a soluble ligand to a cell-surface receptor, however, may be quite a different phenomenon from the adherence of an entire cell to a protein substrate possessing that ligand. Proteins which accumulate significant amounts of AGE in vivo are insoluble interstitial proteins rather than soluble ligands [4-8]. If one is to evaluate receptor-mediated binding of activated monocytes to AGE-proteins, therefore, we believe it is more physiologically relevant to perform cellular adhesion assays to a protein substrate. Consequently, we further evaluated AGE-receptor expression by measuring specific, inhibitable monocyte adhesion to an AGE-protein substrate.

AGE-BSA was chosen as the substrate because background adhesion to control BSA substrate was minimal.
Activated monocytes exhibited a large increase in adhesion to the AGE-BSA substrate compared to the BSA substrate, and such adhesion was competitively inhibited by soluble ligand. This finding demonstrated not only that monocytes adhere more to protein substrates with AGE but also that recognition of AGE on a protein substrate is specific.

As increased AGE are known to form on basement membrane proteins and aortic collagen [23, 24], receptormediated adhesion of activated monocytes to AGE-proteins may occur within the walls of blood vessels. This may result in the local accumulation of monocytes within the vessel wall. Such a process would have direct relevance for the increased incidence of atherosclerosis in diabetes, as intimal monocyte recruitment is thought to be an important early step in the pathogenesis of atherosclerosis [25]. The adhesion of activated monocytes to AGE-proteins within the vessel wall may result in the remodelling of vessel structure following protease secretion $[4,5]$. Activated monocytes accumulating within the intima could also provide an increased local concentration of macrophage-derived growth factor(s), or monokines elaborated by activated monocytes may alternatively stimulate endothelial cells to increase production of growth factors [17]. These processes could contribute to smooth muscle cell and endothelial cell proliferation and thereby play a role in the development of diabetic vascular disease.

Acknowledgments. This work was supported by NIH grant HL36526 to RLH and a pre-doctoral fellowship stipend from the Tennessee affiliate of the American Diabetes Association to MZG.

\section{References}

1. Cerami A, Vlassara H, Brownlee M (1985) Protein glycosylation and the pathogenesis of atherosclerosis. Metab Clin Exp 12 [Suppl 1]: 37-42

2. Winterhalter KH (1985) Nonenzymatic glycosylation of proteins. Prog Clin Biol Res 195: 109-129

3. Vlassara H, Brownlee M, Cerami A (1986) Nonenzymatic glycosylation: role in the pathogenesis of diabetic complications. Clin Chem 32 [Suppl 10]: B37-41

4. Brownlee M, Cerami A, Vlassara H (1988) Advanced products of nonenzymatic glycosylation and the pathogenesis of diabetic vascular disease. Diabetes Metab Rev 4: 437-451

5. Brownlee M, Cerami A, Vlassara H (1988) Advanced glycosylation end products in tissue and the biochemical basis of diabetic complications. N Engl J Med 318: 1315-1321

6. Reynolds TM (1965) Chemistry of nonenzymatic browning. Adv Food Res 14: 167-283

7. Monnier VM, Cerami A (1981) Nonenzymatic browning in vivo: possible process for aging for long-lived proteins. Science 211: 491-493

8. Monnier VM, Cerami A (1982) Nonenzymatic glycosylation and browning of proteins in diabetes. Clin Endocrinol Metab 11:431452

9. Sakurai T, Takahashi H, Tsuchiya S (1984) New fluorescence of nonenzymatically glycosylated human serum albumin. FEBS Lett 176: 27-31

10. Vlassara H, Brownlee M, Cerami A (1985) High-affinity receptor-mediated uptake and degradation of glucose-modified proteins: a potential mechanism for the removal of senescent macromolecules. Proc Natl Acad Sci USA 82: 5588-5592 
11. Vlassara H, Brownlee M, Cerami A (1986) Novel macrophage receptor for glucose-modified proteins is distinct from previously-described scavenger receptors. J Exp Med 164: 13011309

12. Radoff S, Vlassara H, Cerami A (1988) Characterization of a solubilized cell surface binding protein on macrophages specific for proteins modified nonenzymatically by advanced glycosylated end products. Arch Biochem Biophys 263: 418-423

13. Vlassara H, Brownlee M, Cerami A (1988) Specific macrophage receptor activity for advanced glycosylation end products inversely correlates with insulin levels in vivo. Diabetes 37: 456-461

14. Dorn AR, Moriarty CS, Osborne JP, Schultz LC, McCarthy GP, Lister KA, Horne LA (1986) A new system for mononuclear cell separation. Am Clin Prod Rev 5: 26-33

15. Fraker PJ, Speck JC (1978) Protein and cell membrane iodinations with a sparingly soluble chloroamide, 1,3,4,6-tetrachloro3a,6a-diphenylglycoluril. Biochem Biophys Res Comm 80: 849857

16. Vlassara H, Valinsky J, Brownlee M, Cerami C, Nishimoto S, Cerami A (1987) Advanced glycosylation endproducts on erythrocyte cell surface induce receptor-mediated phagocytosis by macrophages. A model for turnover of aging cells. J Exp Med 166: 539-549

17. Vlassara H, Brownlee M, Manogue KR, Dinarello CA, Pasagian A (1988) Cachectin/TNF and IL-1 induced by glucose-modified proteins: role in normal tissue remodeling. Science 240 : $1546-1548$

18. Molvig J, Baek L, Christensen P, Manogue KR, Vlassara H, Platz P, Nielsen LS, Svejgaard A, Nerup J (1988) Endotoxinstimulated human monocyte secretion of interleukin 1, tumour necrosis factor alpha, and prostaglandin E2 shows stable interindividual differences. Scand J Immuno 27: 705-716
19. Chollet-Martin S, Ollivier V, Amiral J, de-Prost D (1988) Binding of an anti-D dimer monoclonal antibody to endotoxin-activated monocytes. Demonstration by immunogold-silver staining. Thrombos Res 52:1-9

20. Henry MM, Moore JN (1988) Endotoxin-induced procoagulant activity in equine peripheral blood monocytes. Circ Shock 26: 297-309

21. Lasser A (1983) The mononuclear phagocytic system: a review. Hum Pathol 14: 108-126

22. Lee SHS, Epstein LB (1980) Reversible inhibition by interferon of the maturation of human peripheral blood monocytes to macrophages. Cell Immunol 50: 177-190

23. Nicholls K, Mandel TE (1989) Advanced glycosylation end-products in experimental murine diabetic nephropathy: effect of islet isografting and of aminoguanidine. Lab Invest 60:486-491

24. Brownlee M, Vlassara H, Kooney A, Ulrich P, Cerami A (1986) Aminoguanidine prevents diabetes-induced arterial wall protein cross-linking. Science 232: 1629-1632

25. Schwarz CJ, Sprague EA, Kelley JL, Valente AJ, Suenram CA (1985) Aortic intimal monocyte recruitment in the normo and hypercholesterolemic baboon. Virch Arch A 405: 175-191

Received: 24 August 1989

and in revised form: 12 February 1990

Dr. R. L. Hoover

Department of Pathology

School of Medicine

Vanderbilt University

Nashville, TN 37232

USA 